\title{
Clinical and biochemical profile of Guillain Barré Syndrome in Pakistan
}

Rashid Iqbal, PhD, Muhammad J. Asad, PostDoc, Muhammad B. Shah, PhD, Raja T. Mahmood, PhD, Saima Siddiqi, PostDoc.

\begin{abstract}

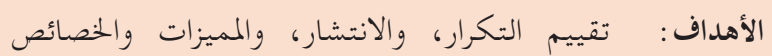
الكيميائية الحيوية لمتلازمة جيلان باريه (GBS) . الأنمار، والمين.

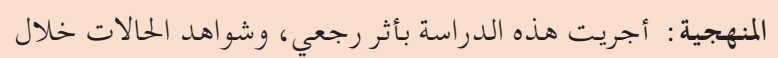

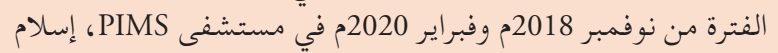

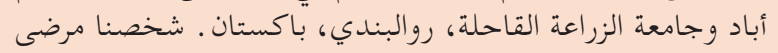

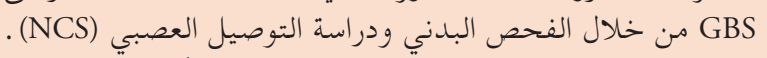

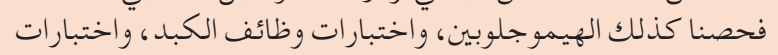

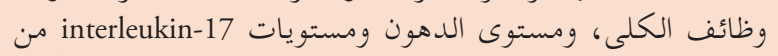

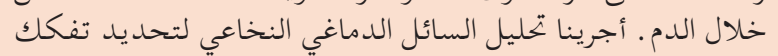
الخحلايا البولية (ACD) الجرينا تحليل

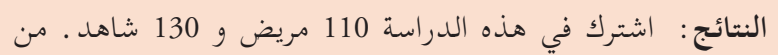

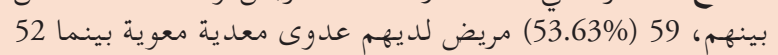

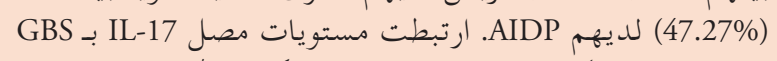

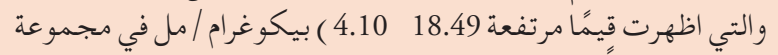

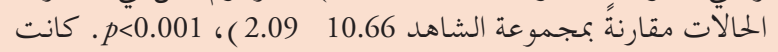
بروتينات CSF ذات دلالة إحصائية

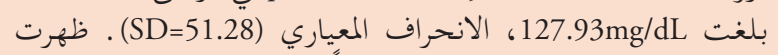

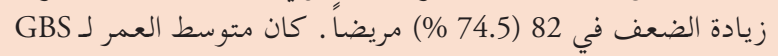

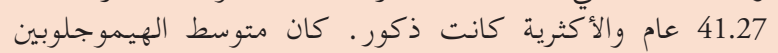

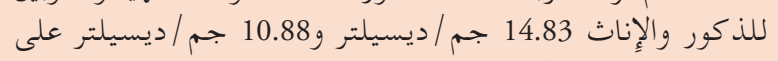

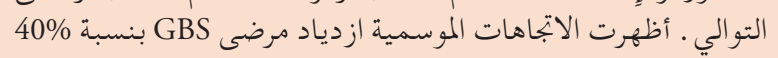

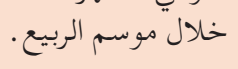

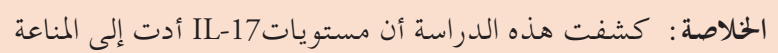

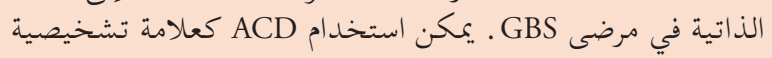

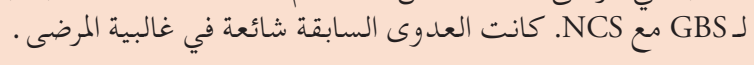

Objectives: To evaluate the frequency, distribution, characteristics, and biochemical features of GuillainBarré syndrome (GBS).

Methods: This retrospective, case-control study was conducted between November 2018 and February 2020 at PIMS Hospital, Islamabad and Arid Agriculture University, Rawalpindi, Pakistan. The GBS patients were diagnosed through physical examination and nerve conduction study
(NCS). Hemoglobin (Hb), liver function tests, renal function tests, lipid profile, and interleukin-17 levels were investigated through the blood. Cerebrospinal fluid analysis (CSF) was performed to measure albuminocytological dissociation (ACD).

Results: One hundred and ten patients and 130 controls participated in this study. Fifty-nine $(53.63 \%)$ patients had gastrointestinal infection while $52(47.27 \%)$ had AIDP. IL17 serum levels were associated with GBS showing elevated values $18.49 \mathrm{pg} / \mathrm{mL}(\mathrm{SD}=4.10)$ in cases as compared to controls $10.66(\mathrm{SD}=2.09), p<0.001$. The CSF proteins were statistically significant in GBS patients, $127.93 \mathrm{mg} / \mathrm{dL}$ $(\mathrm{SD}=51.28), p=0.002$. Ascending weakness was observed in $82(74.5 \%)$ patients. The results showed that the mean age value of GBS patients was 41.27 years, showing males preponderance. The mean $\mathrm{Hb}$ value for males and females was $14.83 \mathrm{~g} / \mathrm{dL}$ and $10.88 \mathrm{~g} / \mathrm{dL}$ respectively. Seasonal trends in the disease showed that $40 \%$ of GBS patients had infections during the spring.

Conclusion: The results of the current study suggest that IL17 levels trigger autoimmunity in GBS patients. The ACD could be used as a diagnostic marker of GBS along with NCS. Antecedent infections were common in a majority of GBS patients.

Neurosciences 2021; Vol. 26 (3): 242-247 doi: $10.17712 / n s j .2021 .3 .20200178$

From Arid Agriculture University (Iqbal, Asad, Shah), Rawalpindi, from Department of Biotechnology (Mahmood), Mirpur University of Science and Technology, Azad Kashmir, from Institute of Biotechnology and Genetic Engineering (Siddiqi), KRL Hospital, Islamabad, Pakistan.

Received 9th December 2020. Accepted 17th February 2021.

Address correspondence and reprint request to: Dr. Muhammad J. Asad, University Institute of Biochemistry and Biotechnology \& National Center of Industrial Biotechnology, PMAS-Arid Agriculture University, Rawalpindi, Pakistan. E-mail: javaidasad@uaar.edu.pk ORCID ID: https://orcid.org/0000-0002-4130-7573

Cuillain-Barré syndrome (GBS) is diagnosed $\checkmark$ by ascending weakness of limbs, acute flaccid paralysis, and albuminocytological dissociation (ACD). GBS was first defined in 1916. ${ }^{1}$ The GBS has been the utmost cause of flaccid paralysis throughout the world. Several studies about the immunopathogenesis of GBS 
proposed that this disease encompasses a set of peripheral nerve disorders, each discriminated by underlying pathophysiology, weakness in the limbs, and underlying pathophysiology. ${ }^{2}$ There are many clear indications about the autoimmune basis of this syndrome and autoantibody profile has been supportive in approving clinical and electrophysiological connection of GBS to certain other peripheral nerves conditions. ${ }^{2}$

The global annual incidence of GBS has been reported as 0.81-1.89 cases per 100000 individuals. ${ }^{1,3}$ Men are more susceptible than women and are 1.78 times more affected. ${ }^{3}$ T-lymphocytes produce cellmediated immunity and have several subclasses. Thelper 17 (Th17), a subclass of T-lymphocytes, links innate immunity with adaptive immunity. Th17 cells are involved in several inflammatory and autoimmune diseases. ${ }^{4}$ These cells produce several cytokines including 1L-17A, IL-17F, IL21, and IL-22A. Many white blood cells (WBCs) produce IL-17 including natural killer T-cells (NKT), neutrophils, CD8+ cells, mast cells, and Th17 cells. A genetic linkage of IL-17A and IL-17F has been found and share $50 \%$ homology. Both cytokines (IL-17A, IL-17F) act similarly on different kinds of cells to bring an expression of cytokines and chemokines. ${ }^{5}$ The IL-17 cytokines are found to be involved in neutrophils aggregation and activating innate immune cells and thus play a central role in the pathogenesis of autoimmune diseases. ${ }^{6}$

Campylobacter jejuni infection is the most prevalent preceding event involved in GBS followed by Cytomegalovirus. ${ }^{7}$ The signs and symptoms of GBS consist of symmetrical weakness, numbness, tingling sensation, pain, irregular blood pressure, tachycardia, and bradycardia. Generally, about 2 weeks next to infection, paralysis starts to appear and reaches its peak in one month. Clinical management of GBS includes plasmapheresis and intravenous immunoglobulin therapy. ${ }^{8}$ This study intended to measure the difference of biochemical parameters between cases and controls. It was hypothesized that serum IL-17 levels and ACD in Cerebrospinal fluid (CSF) are associated with GBS.

Methods. Subjects. This research was performed at the Pakistan Institute of Medical Sciences, Islamabad, Pakistan from November 2018 to February 2020. Laboratory analyses were conducted at the Department of Biochemistry, Biotechnology and Biochemistry Laboratory, PMAS, Arid Agriculture University, Rawalpindi, Pakistan. This study was conducted according to the principles of the Helsinki declaration. Inclusion criteria: All the diagnosed patients of GBS having no other autoimmune disease were included in the study irrespective of age and gender.
Exclusion criteria. Patients with diseases other than GBS were excluded. One hundred and ten (110) cases and 130 healthy controls participated in this casecontrol study. There were 74 males and 36 females patients while 87 males and 43 females in the healthy control participants. Age-wise distribution of patients was as follows: under 12 years $=01,13-25$ years $=18$, 26-35 years $=26,36-49$ years $=26$, Above 50 years= 39. Age-wise distribution of control participants was: Under 12 years $=03,13-25$ years $=23,26-35$ years $=31$, $36-49$ years $=32$, above 50 years $=41$. All the patients signed informed consent and the study was approved by the institutional ethics committee. Diagnosed patients of GBS, fulfilling the diagnostic criteria regardless of gender and age, were enrolled. The diagnosis was made by physical examination, EMG, NCS, and CSF analysis. We generated a questionnaire to gather the thorough history of GBS patients. Physical examination of each patient was performed by Neurologists. A widely accepted GBS disability score was employed to determine the functional status of patients. This scoring criterion was primarily defined by Hughes et $\mathrm{al}^{9}$ in 1978 and afterward, several iterations have appeared. According to this criterion, the patient's disability was scaled from 0 to 6 , such as 0 - No signs and symptoms having normal body functions, 1 - the appearance of little signs and symptoms and able to run properly, 2- unable to run but have the capability to walk independently for about 10 meters, 3 - incapable to walk for 10 -meters independently, 4- unable to walk and bound to chair or bed, 5 -required assisted ventilation, 6 - death. ${ }^{10}$

IL-17 levels determination. The ELISA technique, utilizing human IL-17A ELISA kit manufactured by Promokine, (Cat. No. PK-EL-62716) was employed for measuring serum IL-17 levels. This double antibody

Table 1 - Comparison of IL-17 levels between cases and controls.

\begin{tabular}{|c|c|c|c|c|c|c|}
\hline Subjects & $\mathrm{n}$ & Mean & SD & Min & Max & $P$-value \\
\hline \multicolumn{7}{|c|}{ GBS variants } \\
\hline AIDP & 52 & 18.0385 & 4.26772 & 11.3 & 26 & \multirow[t]{4}{*}{.567} \\
\hline AMAN & 39 & 18.8872 & 3.90871 & 12.4 & 27.8 & \\
\hline AMSAN & 17 & 18.6412 & 4.28559 & 12.4 & 25.5 & \\
\hline MFS & 2 & 21.45 & 1.48492 & 20.4 & 22.5 & \\
\hline \multicolumn{7}{|l|}{ Cases } \\
\hline GBS & 110 & 18.4945 & 4.10881 & 11.3 & 27.8 & \multirow[t]{3}{*}{$<.001$} \\
\hline \multicolumn{6}{|l|}{ Controls } & \\
\hline $\mathrm{HC}$ & 130 & 10.66 & 2.09534 & 5.3 & 13.5 & \\
\hline \multicolumn{7}{|c|}{$\begin{array}{l}\text { Min - Minimum, Max - Maximum, GBS - Guillain Barre } \\
\text { Syndrome, AIDP -Acute inflammatory demyelinating } \\
\text { polyneuropathy, AMAN - Acute motor axonal neuropathy, } \\
\text { MFS - Miller Fischer Syndrome, n - Number of subjects, SD - } \\
\text { Standard Deviation, HC - Healthy controls without disease }\end{array}$} \\
\hline
\end{tabular}


Table 2 - The CSF findings in GBS patients significant difference of CSF protein between AIDP and AMSAN, $p=0.001$, followed by AIDP and AMAN, $p=0.015$

\begin{tabular}{lccccc}
\hline GBS variant (\%) & Mean & SD & Minimum & Maximum & $P$-value \\
\hline AIDP (47.27) & 145.308 & 39.9114 & 38 & 199 \\
AMAN (35.45) & 119.895 & 53.7698 & 30 & 198 & 0.002 \\
AMSAN (15.45) & 97.412 & 60.7547 & 30 & 197 & 95 \\
MFS (1.81) & 92.5 & 3.5355 & 90 & 199 \\
Total (100) & 127.935 & 51.2898 & 30 & \\
\hline AIDP - acute inflammatory demyelinating polyneuropathy, AMAN - Acute motor axonal neuropathy, AMSAN \\
- Acute motor sensory axonal neuropathy, MFS - Miller Fischer syndrome, CSF - Cerebrospinal fluid, GBS - \\
\multicolumn{5}{c}{ Guillain-Barré syndrome, AIDP - Acute inflammatory demyelinating polyneuropathy } \\
\hline \multicolumn{7}{c}{}
\end{tabular}

Table 3 - Clinical parameters and characteristics of GBS patients.

\begin{tabular}{|c|c|c|c|c|c|c|}
\hline Parameters & AIDP & AMAN & AMSAN & MFS & Total & $\mathrm{P}$-value \\
\hline $\begin{array}{l}\text { Sex, } n(\%) \\
\text { Male } \\
\text { Female }\end{array}$ & $\begin{array}{l}29(55.76) \\
23(44.23)\end{array}$ & $\begin{array}{l}27(69.23) \\
12(30.76)\end{array}$ & $\begin{array}{c}16(94.11) \\
1(5.88)\end{array}$ & $2(100)$ & $\begin{array}{l}74(67.27) \\
36(32.72)\end{array}$ & .021 \\
\hline $\begin{array}{l}\text { Age, years } \\
\text { Mean }(\mathrm{SD})\end{array}$ & $41.27(16.38)$ & $36.33(15.35)$ & $39.59(16.56)$ & $33(18.38)$ & $39.11(16.0)$ & .495 \\
\hline $\begin{array}{l}H b, \text { mean }(S D) \\
\text { Male } \\
\text { Female }\end{array}$ & $\begin{array}{l}14.6(0.86) \\
10.9(1.20)\end{array}$ & $\begin{array}{l}14.9(1.04) \\
10.7(1.23)\end{array}$ & $\begin{array}{l}14.8(1.25) \\
11.2(0.85)\end{array}$ & $15.4(0.35)$ & $\begin{array}{l}14.83(1.01) \\
10.88(1.18)\end{array}$ & $\begin{array}{l}.597 \\
.647\end{array}$ \\
\hline $\begin{array}{l}L F T \text {, mean }(S D) \\
\text { T. Bil } \\
\text { ALT }\end{array}$ & $\begin{array}{l}0.73(0.36) \\
28(11.4)\end{array}$ & $\begin{array}{l}0.73(0.38) \\
31(13.3)\end{array}$ & $\begin{array}{l}0.83(0.39) \\
30(17.4)\end{array}$ & $\begin{array}{l}0.55(0.70) \\
43(12.7)\end{array}$ & $\begin{array}{l}0.74(0.37) \\
30(13.1)\end{array}$ & $\begin{array}{l}.674 \\
.416\end{array}$ \\
\hline $\begin{array}{l}R F T \text {, mean }(S D) \\
\text { Urea } \\
\text { Creat }\end{array}$ & $\begin{array}{c}30(11.1) \\
0.63(0.16)\end{array}$ & $\begin{array}{c}33(13.7) \\
0.67(0.16)\end{array}$ & $\begin{array}{c}32(8.1) \\
0.68(0.19)\end{array}$ & $\begin{array}{c}29(0.70) \\
0.83(0.07)\end{array}$ & $\begin{array}{c}31(11.6) \\
0.66(0.17)\end{array}$ & $\begin{array}{l}.467 \\
.314\end{array}$ \\
\hline $\begin{array}{l}\text { Lipid, mean }(S D) \\
\text { Chol } \\
\mathrm{Tg}\end{array}$ & $\begin{array}{l}187(51) \\
133(32)\end{array}$ & $\begin{array}{l}181(46) \\
139(33)\end{array}$ & $\begin{array}{l}190(58) \\
132(38)\end{array}$ & $\begin{array}{l}194(55) \\
117(3.5)\end{array}$ & $\begin{array}{l}186(50) \\
135(33)\end{array}$ & $\begin{array}{l}.171 \\
.501\end{array}$ \\
\hline $\begin{array}{l}\text { Antecedent infection, } \\
(\%) \text { GI } \\
\text { URTI } \\
\text { Fever } \\
\text { None }\end{array}$ & $\begin{array}{l}36(69.23) \\
9(17.30) \\
1(1.92) \\
6(11.53)\end{array}$ & $\begin{array}{c}16(41.0) \\
5(12.82) \\
10(25.64) \\
8(20.51)\end{array}$ & $\begin{array}{l}6(35.29) \\
3(17.64) \\
2(11.76) \\
6(35.29)\end{array}$ & $\begin{array}{l}1(50) \\
1(50)\end{array}$ & $\begin{array}{l}59(53.63) \\
17(15.45) \\
13(11.81) \\
21(19.0)\end{array}$ & .013 \\
\hline $\begin{array}{l}\text { Seasonal trends, } n(\% \text {, } \\
\text { Summer } \\
\text { Winter } \\
\text { Autumn } \\
\text { Spring }\end{array}$ & $\begin{array}{l}11(21.15) \\
16(30.76) \\
25(48.07)\end{array}$ & $\begin{array}{c}8(20.51) \\
11(28.20) \\
10(25.64) \\
9(23.07)\end{array}$ & $\begin{array}{l}1(5.88) \\
6(35.29) \\
1058.82)\end{array}$ & $2(100)$ & $\begin{array}{c}20(18.19) \\
27(24.54) \\
16(14.54) \\
44(40)\end{array}$ & $<.001$ \\
\hline $\begin{array}{l}\text { Residence, } n(\%) \\
\text { Urban } \\
\text { Rural }\end{array}$ & $\begin{array}{l}35(67.30) \\
17(32.69)\end{array}$ & $\begin{array}{c}4(10.25) \\
35(89.74)\end{array}$ & $\begin{array}{c}1(5.88) \\
16(94.11)\end{array}$ & $2(100)$ & $\begin{array}{l}40(36.3) \\
70(63.6)\end{array}$ & $<.001$ \\
\hline $\begin{array}{l}\text { Clinical features, } n(\%, \\
\text { Respiratory distress } \\
\text { Walking difficulty } \\
\text { Ascending weakness } \\
\text { Tingling }\end{array}$ & $\begin{array}{l}7(13.4) \\
31(59.6) \\
38(73.0) \\
29(55.7)\end{array}$ & $\begin{array}{c}6(15.3) \\
24(61.5) \\
29(74.3) \\
21(53.84)\end{array}$ & $\begin{array}{c}3(17.6) \\
10(58.8) \\
12(70.5) \\
9(52.9)\end{array}$ & $\begin{array}{l}1(50) \\
1(50 \\
1(50)\end{array}$ & $\begin{array}{c}9(8.1) \\
70(63.6) \\
82(74.5) \\
71(64.5)\end{array}$ & $<.001$ \\
\hline
\end{tabular}

sandwich ELISA consisted of capture and detecting antibodies. Mouse anti-human IL-17 monoclonal antibodies were used as capture antibodies while detecting antibodies comprised of biotinylated antibodies reactive with human IL-17. The assay was performed according to the manufacturer's instructions (Promokine, Heidelberg, Germany). ${ }^{11}$ Fully automated AMP Platos RII plate reader was employed (AMEDA 
Labrodiagnostik, Austria) for measuring absorbance at $450 \mathrm{~nm}$. A standard curve was produced to determine quantities of IL-17 serum levels. ${ }^{12}$

CSF analysis. The CSF analysis was performed after ten days of hospital admission of the patients. Lumbar puncture technique was used for CSF collection and fluid was put into polypropylene tubes. WBC count was done by Sysmex KX-21 automated hematology analyzer (Sysmex Corporation, Japan) and crosschecked by an improved Neubar chamber by using a light microscope. ${ }^{13}$ Protein (albumin) levels were determined by utilizing DiaSys reagent (diagnostic system). Protein was measured by automated chemistry analyzer AU-480 (Beckman Coulter, USA).

Baseline metabolic profile. Routine biochemical parameters including liver function tests, renal function tests, and lipid profile were performed on the AU-480 chemistry analyzer while Hemoglobin estimation and WBC count were done on Sysmex-Kx-21(Hematology analyzer).

Statistical analysis. The SPSS IBM version 23 was employed for statistical analysis. Mean values, standard deviation, frequencies and percentages of GBS subgroups, antecedent infections, demographic features, and clinical parameters were determined. ANOVA (Analysis of variance), chi-square, and student's t-test were employed to determine the association of GBS with different biochemical, clinical, and demographic features. All these tests were done by keeping alpha 5\%, and CI $95 \%$.

Results. The total participants in this study were 240 (110 patients and 130 healthy controls). Serum IL-17 levels were markedly elevated in cases having mean value $18.49 \mathrm{pg} / \mathrm{mL}(\mathrm{SD}=4.10)$ than controls with mean value $10.66 \mathrm{pg} / \mathrm{mL}(\mathrm{SD}=2.09)$. The main subgroups of GBS including, acute inflammatory demyelinating polyneuropathy (AIDP) showed mean serum IL-17 levels values of $18.03 \mathrm{pg} / \mathrm{mL}(\mathrm{SD}=4.26)$, acute motor axonal neuropathy (MFS) had mean serum IL-17 values of $18.88 \mathrm{pg} / \mathrm{mL}(\mathrm{SD}=3.90)$, acute motor-sensory axonal neuropathy (AMSAN) had mean serum IL-17 values of $18.64 \mathrm{pg} / \mathrm{mL}(\mathrm{SD}=4.28)$ and Miller Fischer syndrome (MFS) had mean serum IL-17 values of $21.45 \mathrm{pg} / \mathrm{mL}$ $(\mathrm{SD}=1.48)$. Very low $p$-value i.e., $p<0.001$, indicated the significance of the results (Table 1).

The ACD is defined as elevated CSF albumin level $(>45 \mathrm{mg} / \mathrm{dL}$ ) along with normal white blood cell count $(<5.0 / \mu \mathrm{L}) .{ }^{14}$ The ACD was found in 95 out of $110 \mathrm{GBS}$ patients. Mean CSF albumin level was $127.93 \mathrm{mg} / \mathrm{dL}$ $(\mathrm{SD}=51.28)$. The AIDP was the most frequent GBS variant (47.27\%) having mean CSF albumin value $145.308 \mathrm{mg} / \mathrm{dL}(\mathrm{SD}=39.911)$ while MFS was the least variant $(1.81 \%)$ with mean CSF albumin value 92.5 $\mathrm{mg} / \mathrm{dL}(\mathrm{SD}=3.835)$ (Table 2).

No significant difference in routine clinical parameters was found between cases and controls and amongst GBS variants. Mean bilirubin (total) was 0.74 $\mathrm{mg} / \mathrm{dL}(\mathrm{SD}=0.37), p=0.674$. AIDP and AMAN variants have total bilirubin value near to mean value i.e., 0.73 $\mathrm{mg} / \mathrm{dL}$. ALT mean value was $30 \mathrm{U} / \mathrm{L}(\mathrm{SD}=13.1), p=.416$ while AMAN \& AMSAN variants have values closer to total mean value i.e., $31 \mathrm{U} / \mathrm{L}$ and $30 \mathrm{U} / \mathrm{L}$ respectively. Urea total mean value was $31 \mathrm{mg} / \mathrm{dL}(\mathrm{SD}=11.6)$ and, $p=.467$ while AIDP have $30 \mathrm{mg} / \mathrm{dL}$ and AMSAN have $32 \mathrm{mg} / \mathrm{dL}$. Cholesterol was $186 \mathrm{mg} / \mathrm{dL}(\mathrm{SD}=50), p=.17$, creatinine $0.66 \mathrm{mg} / \mathrm{dL}(\mathrm{SD}=0.17), p=.314$, triglyceride $135 \mathrm{mg} / \mathrm{dL} \quad(\mathrm{SD}=33), p=.50$. The most common preceding infection was gastrointestinal infection (GI) found in $59(53.63 \%)$ patients and the least was fever observed in $13(11.81 \%)$ patients. The average age of the patients was 39.11 years $(\mathrm{SD}=16)$. Clinical features consisted of ascending weakness (74.5\%), tingling sensation (64.5\%), walking difficulty $(63.6 \%)$, and respiratory distress $(8.1 \%)$. The occurrence of GBS was increased during the spring (March-May) (40\%) (Table 3).

Hughes' disability scoring was performed and no patient was having "no signs and symptoms having normal body functions (score 0)", no patient having "appearance of little signs and symptoms and able to run properly (score 1) while 13 patients had score 2 (unable to run but have the capability to walk independently for about 10 meters). There were 36 patients incapable to walk for 10-meters independently (score 3), 33 patients unable to walk and bound to a chair or bed (score 4), 27 patients required assisted ventilation (score 5) and 1 patient died (score 6). Most of the patients have severe medical conditions and have abnormal levels of various chemical parameters.

Discussion. Several signs of the involvement of autonomic fibers are present in GBS patients such as constipation, vasomotor disturbances, and urinary retention. Distant areas of Pakistan are deprived of health facilities due to which very small data of GBS is accessible from Pakistan. ${ }^{15}$

IL-17 serum levels were markedly raised in cases showing that Th17 cells were activated in the autoimmune responses of GBS. Hence, it can be concluded that IL-17 levels trigger autoimmune responses in GBS. ${ }^{16}$ In the current research study, we had detected elevated IL-17 levels in patients i.e., $18.49 \mathrm{pg} / \mathrm{mL}(\mathrm{SD}=4.10)$. In another study, Li et al. demonstrated, $17.39 \mathrm{pg} / \mathrm{mL}(\mathrm{SD}=4.87) \mathrm{IL}-17$ levels in GBS patients. ${ }^{12}$ 
Cerebrospinal fluid is generally acellular. Albumin (protein) levels might be normal in 1st week of the illness but there could be an upsurge in protein level if determined 2 or 3 weeks later. Raised CSF protein quantity in Guillain-Barré syndrome is generally related to higher permeability between blood and CSF barrier. ${ }^{17}$ In this study, 95 (86.36\%) cases exhibited ACD in CSF analysis. Albuminocytological dissociation in the CSF study presented a noteworthy difference amongst axonal and demyelinating variants $(p=0.002)$. The increase in CSF protein level in Guillain-Barré syndrome is ascribed as damage to myelin sheath or axons resulting in the release of proteins into the cerebrospinal fluid. ${ }^{18}$ In this study, the average CSF protein level was 127.93 (51.28), ranging from 30-199. These figures are in level with research performed by Nomani and his group. ${ }^{19}$

The current results indicated that all age groups and both sexes (male and female) are affected by GBS. The male to female gender ratio varies in literature ranging from 1.5 to 2.7. This study presented mean age of 39.11(16) years ranging from 11 to 70 years and a male to female ratio of $2: 1$. Male preponderance has been reported by many researchers. ${ }^{12} \mathrm{~A}$ research from Turkey described average age of 54.21 (17.32) years. ${ }^{20}$

The main GBS variant in this study was AIDP $(52$ patients out of 110), which showed that AIDP is the core GBS subgroup in Pakistan. Another study from Pakistan also showed AIDP as the most common variant (46\%). ${ }^{21}$ Another research of 51 cases, from India, described AIDP (86.3\%), AMSAN (5.9\%), and AMAN $(7.8 \%) .{ }^{22}$ The most common primary symptom in our study was ascending weakness followed by tingling. Many patients had lower limbs weakness while arms weakness was present in few patients. These figures are in line with research conducted by Debnath and his colleagues. $^{23}$

Many types of researches presented the history of a preceding event in 50 to $71 \%$ of GBS patients as is presented by our research. The elevated incidence of GI infections in this study might be due to poor hygienic conditions and elevated occurrence of gut pathogens in our country. ${ }^{24,25}$ Although, many studies have not reported seasonal trends. Few studies described seasonal clustering during the winter and spring. In this research, we presented a seasonal clustering during spring months (March to May) (40\%), while some patients were found during autumn (September to November) (14.54\%), winter (December to February) (24.54\%), and summer (June to August) (18.19\%). ${ }^{26}$

In conclusion, our study demonstrated increased levels of IL-17 in GBS. This is the first study focusing on the role of IL-17 in GBS in the Pakistani population. We have found a significant association of IL-17 with GBS. Besides, we have observed ACD in the majority of patients. ACD can be used as a diagnostic marker of GBS along with NCS and EMG.

Acknowledgment. We are grateful to the Pakistan Institute of Medical Sciences for providing the samples and data of patients to conduct this study. We are also thankful to the patients for giving their data. We would like to thank Laureate English Academy for providing English language editing service.

\section{References}

1. Teo E, Azwra A, Jones R, Gazzard BG, Nelson M. GuillainBarre syndrome following immune reconstitution after antiretroviral therapy for primary HIV infection. J HIV Ther 2007; 12: 62-63.

2. Yuki N, Hartung H-P. Guillain-Barré syndrome. N EnglJ Med 2012; 366: 2294-2304.

3. Shang P, Zhu M, Wang Y, Zheng X, Wu X, Zhu J, et al. Axonal variants of Guillain-Barré syndrome: an update. J Neurol 2020: 1-18.

4. Debnath M, Nagappa M, Murari G, Taly AB. IL-23/IL-17 immune axis in Guillain Barre syndrome: exploring newer vistas for understanding pathobiology and therapeutic implications. Cytokine 2018; 103: 77-82.

5. Wu X, Wang J, Liu K, Zhu J, Zhang H-L. Are Th17 cells and their cytokines a therapeutic target in Guillain-Barré syndrome? Expert Opin Ther Targets 2016; 20: 209-222.

6. Wang Z, Zhang J, Mi J, Ma H, Zhao D. Expression and significance of interleukin-17 and interleukin-22 in the serum and the lower esophageal sphincter of patients with achalasia. Saudi J Gastroenterol 2018; 24: 242-248.

7. Berciano J, Orizaola P, Gallardo E, Pelayo-Negro AL, SánchezJuan P, Infante J, et al. Very early Guillain-Barré syndrome: A clinical-electrophysiological and ultrasonographic study. Clin Neurophysiol Pract 2019; 5: 1-9.

8. Zeppelin Z, Kristensen S, Fuglsang-Frederiksen A, Andersen H, Harbo L, Levison L, et al. P85-F The utility of MVRCs in detection of early axonal involvement in GBS. Clinical Neurophysiology 2019; 130: e92.

9. Tunç A. Early predictors of functional disability in GuillainBarré Syndrome. Acta Neurol Belg 2019; 119: 555-559.

10. Van Koningsveld R, Steyerberg EW, Hughes RA, Swan AV, van Doorn PA, Jacobs BC. A clinical prognostic scoring system for Guillain-Barré syndrome. Lancet Neurol 2007; 6: 589-594.

11. Roth S, Spalinger MR, Gottier C, Biedermann L, Zeitz J, Lang $S$, et al. Bilberry-derived anthocyanins modulate cytokine expression in the intestine of patients with ulcerative colitis. PLoS One 2016; 11: e0154817.

12. Li S, Yu M, Li H, Zhang H, Jiang Y. IL-17 and IL-22 in cerebrospinal fluid and plasma are elevated in Guillain-Barre syndrome. Mediators Inflamm 2012; 2012: 260473 ..

13. Maleb A, Bouayadi O, El Malki J, Rifai S, Lamrabat S, Benaissa E, et al. Cytological examination of cerebrospinal fluid: Sysmex UF-1000i versus optical microscopy. Anal Biochem 2020; 589: 113501.

14. Kalra V, Chaudhry R, Dua T, Dhawan B, Sahu JK, Mridula B. Association of Campylobacter jejuni infection with childhood Guillain-Barré syndrome: a case-control study. J Child Neurol 2009; 24: 664-668.

15. Zia MA, Masood Y, Salman MK. Guillain-barré syndrome; autonomic disturbances in children. Professional Medical J 2018; 25 : 538-544. 
16. Lu M-O, Zhu J. The role of cytokines in Guillain-Barré syndrome. J Neurol 2011; 258: 533-548.

17. Akbayram S, Doğan M, Akgün C, Peker E, Sayin R, Aktar $\mathrm{F}$, et al. Clinical features and prognosis with Guillain-Barré syndrome. Ann Indian Acad Neurol 2011; 14: 98-102.

18. Brettschneider J, Petzold A, Süssmuth S, Tumani $H$. Cerebrospinal fluid biomarkers in Guillain-Barré syndromeWhere do we stand? J Neurol 2009; 256: 3-12.

19. Nomani AZ, Iqbal M, Majeed H, Badshah M, Nabi S, Jan Z, et al. Albuminocytological dissociation in different electrophysiological gbs variants. PakJ of Neurological Sciences 2015; 10: 32-36.

20. Cetiner M, Seyit M, Akdağ G, Demirbaş H, Temel Ö, Kabay SC. Factors Associated with Prognosis in Patients with Guillain-Barré Syndrome. Turk J of Neurol 2019; 25: 140-145.

21. Shafqat S, Khealani B, Awan F, Abedin S. Guillain-Barré syndrome in Pakistan: similarity of demyelinating and axonal variants. Eur J Neurol 2006; 13: 662-665.
22. Kalita J, Misra U, Das M. Neurophysiological criteria in the diagnosis of different clinical types of Guillain-Barre syndrome. J Neurol Neurosurg Psychiatry 2008; 79: 289-293.

23. Debnath B, Hussain ME, Haque N, Khan AAM, Mian MF, Islam $\mathrm{MN}$, et al. Clinical and ElectrophysiologicAspects of Guillain Barre Syndrome among Children: Experience at Referral Tertiary Care Hospital in Bangladesh. Journal of National Institute of Neurosciences Bangladesh 2019; 5: 2-7.

24. Yakoob MY, Rahman A, Jamil B, Syed NA. Characteristics of patients with Guillain Barre Syndrome at a tertiary care centre in Pakistan, 1995-2003. J Pak Med Assoc 2005; 55: 493-496.

25. Zhang B, Wu X, Shen D, Li T, Li C, Mao M, et al. The clinical characteristics and short-term prognosis in elderly patients with Guillain-Barré syndrome. Medicine (Baltimore) 2017; 96: e5848.

26. Webb AJ, Brain SA, Wood R, Rinaldi S, Turner MR. Seasonal variation in Guillain-Barré syndrome: a systematic review, meta-analysis and Oxfordshire cohort study. J Neurol Neurosurg Psychiatry 2015; 86: 1196-1201.

\section{Supplements}

* Supplements will be considered for work including proceedings of conferences or subject matter covering an important topic

* Material can be in the form of original work or abstracts.

* Material in supplements will be for the purpose of teaching rather than research.

* The Guest Editor will ensure that the financial cost of production of the supplement is covered.

* Supplements will be distributed with the regular issue of the journal but further copies can be ordered upon request.

* Material will be made available on Saudi Medical Journal website 